\title{
Allylic Azides as Potential Building Blocks for the Synthesis of Nitrogenated Compounds
}

\author{
Marcus M. Sá* \\ Departamento de Química, Universidade Federal de Santa Catarina, 88040-900 Florianópolis - SC, Brazil

\begin{abstract}
Neste trabalho foi investigado o comportamento de alil azidas e alil iminas polifuncionais em reações de ciclização intramolecular, buscando desenvolver novas metodologias para a síntese de heterociclos nitrogenados. (E)-3-Aril-2-(azidometil)propenoatos reagem com trifenilfosfina na presença de aldeídos em uma reação tandem Staudinger/aza-Wittig, fornecendo $N$-alil iminas em bons rendimentos. A estereoquímica $(E)$ para as ligações $\mathrm{C}=\mathrm{C}$ e $\mathrm{C}=\mathrm{N}$ foi determinada por NOESY. Também é apresentada a formação de 3-carbometoxiquinolina a partir da ciclização de $(E)-2$ (azidometil)-3-fenilpropenoato de metila promovida por $\mathrm{AlCl}_{3}$.
\end{abstract}

The synthetic potential of multifunctional allylic azides and imines in attempted intramolecular cyclizations to nitrogen-containing heterocycles was investigated. Tandem Staudinger/aza-Wittig reaction of (E)-3-aryl-2-(azidomethyl)propenoates with triphenylphosphine and aldehydes yielded $N$-allylic imines in good yield. The $(E)$-stereochemistry of $\mathrm{C}=\mathrm{C}$ and $\mathrm{C}=\mathrm{N}$ bonds was assigned based on NOESY experiments. $\mathrm{AlCl}_{3}$ mediated formation of 3-carbomethoxyquinoline from methyl $(E)$ 2-(azidomethyl)-3-phenylpropenoate is also described.

Keywords: allylic azides, 3-carbomethoxyquinoline, $N$-allylic imines, Staudinger/aza-Wittig reaction, Baylis-Hillman reaction

\section{Introduction}

Organic azides ${ }^{1-3}$ are widely used in synthetic preparation of heterocycles and nitrogen-containing compounds commonly related to natural products and pharmacologically active substances. ${ }^{4-9}$ The reaction of azido compounds with tertiary phosphorus reagents ${ }^{10,11}$ affords phosphorus-nitrogen ylides (the Staudinger reaction $)^{12}$ which can be further converted to many classes of nitrogenated derivatives such as imines, amines, carboxamides and phosphoramides, usually in good yield and high chemoselectivity. ${ }^{13-19}$

Recently we have reported a straightforward synthesis of $\gamma$-azido- $\alpha$-diazo- $\beta$-keto esters ${ }^{20}$ and their chemoselective transformations to 2-azido-3-furanones ${ }^{21}$ and phosphorylaminodiazo esters ${ }^{22}$ under mild conditions and in high yield, illustrating the versatility of multifunctional azido compounds as building blocks through more elaborated structures. Other potentially useful azidecontaining scaffolds for the generation of heterocycles and important synthetic targets include $\beta$-substituted- $\alpha$ -

* e-mail: msa@qmc.ufsc.br

This paper is dedicated to Prof. Albert J. Kascheres on occasion of his $60^{\text {th }}$ birthday (azidomethyl)acrylates, easily obtained by a two-step procedure from $\alpha$-methylene- $\beta$-hydroxy esters (BaylisHillman adducts) ${ }^{23}$ However, the chemical behavior of these densely functionalized allylic azides has been seldom explored. ${ }^{24,25}$ This paper describes the reactivity of $\beta$-substituted- $\alpha$-(azidomethyl)acrylates under different reaction conditions, emphasizing the synthesis of $N$-allyl imines by a tandem Staudinger/aza-Wittig protocol and attempted cyclizations to quinoline and benzazepine system.

\section{Results and Discussion}

Previously reported methyl (E)-2-(azidomethyl)-3phenylpropenoate (1) and methyl (E)-2-(azidomethyl)-3(2-furyl)propenoate (2) were prepared according to the original procedure described by Foucaud, ${ }^{25}$ which is illustrated by the synthesis of the novel methyl $(E)-2$ (azidomethyl)-3-(3,4-methylenedioxyphenyl)propenoate (3). The nucleophile-catalyzed condensation of methyl acrylate and an aldehyde (the Baylis-Hillman reaction) ${ }^{23}$ provides an easy entry to the required $\alpha$-methylene- $\beta$ hydroxy ester $4 .^{26}$ Acetylation of allylic alcohol 4 employing acetic anhydride in pyridine afforded the rearranged ${ }^{27}$ acetate 5 which was treated with sodium azide 
<smiles>COC(=O)/C(=C/c1ccccc1)CN</smiles><smiles>COC(=O)/C(=C/c1ccco1)CN</smiles><smiles>C=C(C(=O)OC)C(O)c1ccc2c(c1)OCO2</smiles>

CONDITIONS: a: $\mathrm{Ac}_{2} \mathrm{O}$, py, rt; b) $\mathrm{NaN}_{3}$, DMSO, rt (71\%, 2 steps).

Scheme 1.

in DMSO to give the allylic azide $\mathbf{3}$ as a crystalline solid in good overall yield (Scheme 1). The $(E)$-stereochemistry was assigned for both $\mathbf{3}$ and $\mathbf{5}$, based on their ${ }^{1} \mathrm{H}$ NMR spectra. The singlet appearing downfield for $\mathbf{3}(\delta$ 7.87) and for $\mathbf{5}(\delta 7.88)$ is typical for $\beta$-olefinic protons $c i s$ to the ester group in $\alpha$-alkyl- $\beta$-arylacrylates. ${ }^{25,28}$ The chemical stability of allylic azides 1-3 is worth of note, as they can be stored for years at $5-10{ }^{\circ} \mathrm{C}$ without significant decomposition. Moreover, these compounds are stable for hours in refluxing toluene and also in the presence of bases like DABCO or $\mathrm{NaH}$.

Allylic azides $\mathbf{1}$ to $\mathbf{3}$ were then treated with common electrophilic reagents (TFA/ $\mathrm{CH}_{2} \mathrm{Cl}_{2} ; \mathrm{TFAA} / \mathrm{py} ; \mathrm{Ti}(i-\mathrm{PrO})$; $\mathrm{SOCl}_{2} / \mathrm{DMF}$; bleach/HOAc) in order to promote azide activation and intramolecular cyclization. However, the starting azides were recovered unchanged after aqueous work up, indicating that a more reactive Lewis acid should be employed. Accordingly, treatment of phenyl derivative 1 with $\mathrm{AlCl}_{3}$ in $\mathrm{CH}_{2} \mathrm{Cl}_{2}$ followed the expected pathway. After reacting for $54 \mathrm{~h}$ starting material was totally consumed and formation of two main products was apparent from ${ }^{1} \mathrm{H}$ NMR spectrum of the crude reaction. The presence of two singlets at $\delta 4.10$ and $\delta 3.90$, with a relative integration of $3 \mathrm{H}$ and $2 \mathrm{H}$, respectively, indicated that each product bears a methoxycarbonyl group. Silica gel chromatography column allowed the isolation of the major product in $23 \%$ yield, as a crystalline solid melting at $74-77{ }^{\circ} \mathrm{C}$. The absence of azide band in the IR and the observation of molecular ion at $m / z=187$ in the MS spectrum imply a loss of $\mathrm{N}_{2}$ (plus $\mathrm{H}_{2}$ ) from the starting azide 1. In addition, its ${ }^{1} \mathrm{H}$ and ${ }^{13} \mathrm{C}$ NMR spectra presented only aromatic peaks downfield (besides the signals for methyl ester group), suggesting that a cyclization to 3-carbomethoxyquinoline $\mathbf{6}$ took place. The spectroscopy data were in agreement with related work describing the synthesis of $\mathbf{6}$ by independent methods, ${ }^{29}$ thus confirming the assigned structure (Scheme 2). On the other hand, the minor product formed in the $\mathrm{AlCl}_{3}$ mediated cyclization of allylic azide $\mathbf{1}$ could not be separated by silica gel chromatography, precluding its characterization. In fact, the low experimental yield obtained for 3 -carbomethoxyquinoline $\mathbf{6}$ was not only associated with an expressive formation of by-products during the reaction, but also with a rather inefficient purification step.

The synthesis of carboxyquinolines and analogs is an active research area because the quinoline backbone is usually encountered in natural products and biologically active compounds..$^{30}$ In a related study, Kim developed a method to prepare carboxyquinolines by oxidative cyclization of allylic tosylamides derived from BaylisHillman adducts. ${ }^{31}$ A related intramolecular cyclization of alkyl azides was reported by Kita, treating 1-azido- $\omega$ -<smiles>CC(=O)C(=Cc1ccccc1)CN</smiles><smiles></smiles><smiles>CC(=O)c1cnc2ccccc2c1</smiles>

6

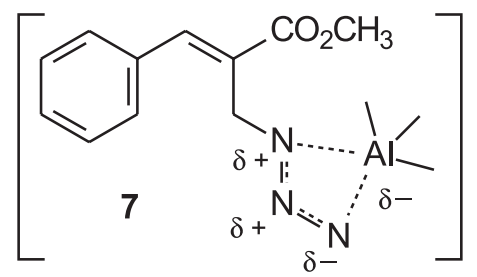


arylalcanes with a combination of phenyliodine(III) bis(trifluoroacetate) and TMSOTf in 2,2,2-trifluoroethanol. ${ }^{32}$ Therefore the $\mathrm{AlCl}_{3}$ mediated allylic azide to quinoline transformation deserved more attention. Unfortunately, however, the low yield obtained for $\mathbf{6}$ could not be improved by simple modifications in reaction parameters such as temperature and solvent. Besides, allylic azides $\mathbf{2}$ and $\mathbf{3}$ were highly sensitive to $\mathrm{AlCl}_{3}$ and decomposed extensively to complex mixtures, probably due to the presence of the furyl and methylenedioxyphenyl functions as oxygenated aromatic moieties acting as Lewis bases.

Although very limited in scope, the above transformation is remarkable and a detailed mechanistic proposal to rationalize the quinoline formation would be a fascinating but rather complex study. One might suggest, however, an initial complexation of azido group with aluminum which activates the carbon-bonded nitrogen to a nucleophilic attack by the aromatic ring (Scheme 2, structure 7). Loss of molecular nitrogen followed by oxidation to the heteroaromatic ring completes the reaction. The proposed mechanism for the cyclization of allylic azide $\mathbf{1}$ could be related to the $\mathrm{AlCl}_{3}$ mediated intramolecular cyclization of aryl azides previously described by Takeuchi. ${ }^{33}$ His elegant kinetic studies supported the formation of an aryl nitrenium- $\mathrm{AlCl}_{3}$ complex as intermediate in aryl azide decomposition.

While the behavior of allylic azido compounds 1-3 toward selected electrophilic reagents was somewhat disappointing, much more consistent results were obtained in reactions with triphenylphosphine and aldehydes, the Staudinger/aza-Wittig reaction. ${ }^{10,11}$ Allylic azide 1 reacted smoothly with triphenylphosphine generating an iminophosphorane intermediate 8 (accompanied by $\mathrm{N}_{2}$ evolution) which was then treated with 3-nitrobenzaldehyde, furnishing $N$-allylic imine 9 as a crystalline solid in $84 \%$ isolated yield. Similarly, treatment of iminophosphorane $\mathbf{8}$ with 2-naphthaldehyde produced the corresponding naphthyl imine $\mathbf{1 0}$ in high yield (Scheme 3). Both imines could be separated from $\mathrm{Ph}_{3} \mathrm{PO}$ and purified by recrystallizations in ethyl ether. Reaction of azide 1 with $\mathrm{Ph}_{3} \mathrm{P}$ and piperonal, however, was less selective and gave a mixture of products that refused to solidify by treatment with ether or any other solvent. Attempts to fractionate the mixture by chromatography in silica gel led to extensive imine decomposition. Similar difficulties were also observed for a reaction involving furyl azide 2, $\mathrm{Ph}_{3} \mathrm{P}$ and 3-nitrobenzaldehyde, precluding product characterization.

On the other hand, $N$-allylic imine $\mathbf{1 1}$ was obtained in good yield and high purity by reacting piperonyl azide $\mathbf{3}$ with $\mathrm{Ph}_{3} \mathrm{P}$ and 3-nitrobenzaldehyde in $\mathrm{CH}_{2} \mathrm{Cl}_{2}$, followed

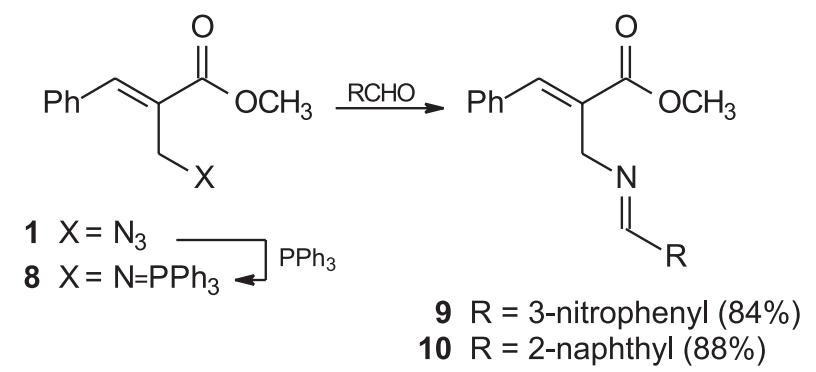

Scheme 3.

by simply evaporating the solvent and triturating with ether. Piperonyl imine $\mathbf{1 1}$ showed an interesting pattern for ${ }^{1} \mathrm{H}$ NMR due to $\mathrm{H}-\mathrm{C}_{\mathrm{sp}^{2}}$ signals well separated from each other, allowing the attribution for hydrogen and carbon nuclei by 2D NMR (HETCOR, COSY). The proposed connectivity for structure $\mathbf{1 1}$ was further confirmed by NOESY, which was particularly useful for stereochemical assignments. Correlation between methylene $\left(\mathrm{CH}_{2}\right)$ and aromatic piperonyl $\left(\mathrm{H}_{1}\right.$ in Figure 1) confirms the previously anticipated $(E)$-geometry for $\alpha$-alkyl- $\beta$-arylacrylate series. Furthermore, a correlation between $\mathrm{CH}_{2}$ and $\mathrm{HC}=\mathrm{N}\left(\mathrm{H}_{9}\right.$ in Figure 1) strongly supports the (E)-stereochemistry for the imine double bond in $\mathbf{1 1}$.
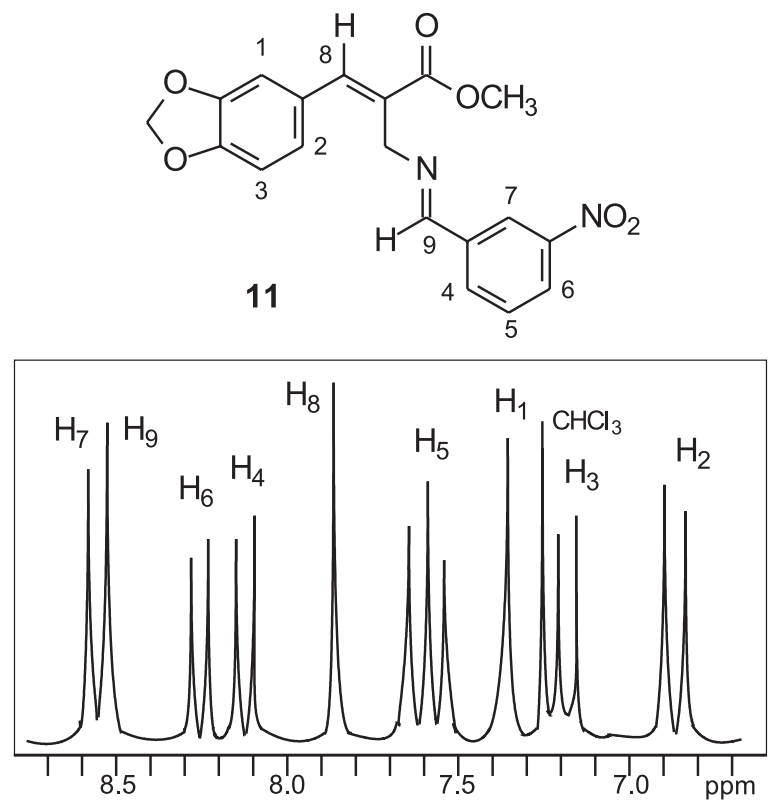

Figure 1. ${ }^{1} \mathrm{H}$ NMR $\left(200 \mathrm{MHz}, \mathrm{CDCl}_{3} / \mathrm{TMS}\right.$ ) of imine 11 (downfield region only).

Nucleophilic 1,2-addition to imines is a valuable method for the synthesis of amines and other nitrogencontaining molecules due to the variety of nucleophiles that can be employed in the reaction. ${ }^{34} \mathrm{~N}$-Allylic imines 9$\mathbf{1 1}$ bearing an array of functional groups in a rather unusual 
structure motivated a preliminary study dealing with their reactivity, emphasizing some attempts to promote intramolecular cyclization to pharmacologically important 2-benzazepine core $\mathbf{1 2}^{35}$ (Scheme 4). Therefore $N$-allylic imines 9-11 were treated with simple electrophilic reagents $\left(\mathrm{SOCl}_{2} / \mathrm{DMF} ; \mathrm{POCl}_{3} ; \mathrm{Me}_{3} \mathrm{SiCl} / \mathrm{I}_{2} ; \mathrm{AlCl}_{3}\right)$ to induce activation of $\mathrm{C}=\mathrm{N}$ imine bond. However, analysis of the crude reactions by ${ }^{1} \mathrm{H}$ NMR detected the presence of starting imines together with a minor amount of products resulting from hydrolysis of $\mathrm{C}=\mathrm{N}$ bond. ${ }^{25}$ Another possible route to a benzazepine structure could be envisaged by initially reacting allylic azide 1 with $\mathrm{Ph}_{3} \mathrm{P}$ and a carboxylic acid, ${ }^{10}$ followed by a homologous Bischler-Napieralsky cyclization $^{36}$ of the preformed $N$-acyl derivative. Again, the tested conditions failed and a complex mixture of products was obtained from the crude reaction.

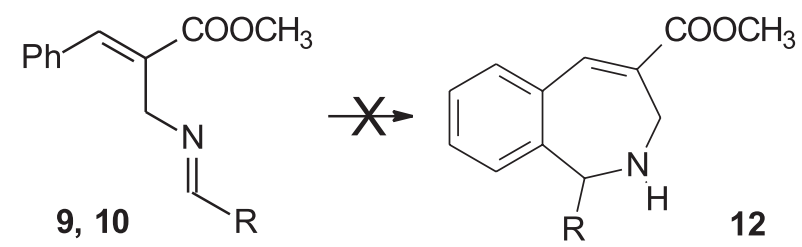

Scheme 4 .

\section{Conclusion}

(E)-3-Aryl-2-(azidomethyl)propenoates 1-3 were easily available from the corresponding $\alpha$-methylene- $\beta$-hydroxy esters in good yield under mild conditions. These allylic azides were quite stable toward the examined electrophilic reagents, except for the $\mathrm{AlCl}_{3}$ mediated cyclization of methyl (E)-2-(azidomethyl)-3-phenylpropenoate $\mathbf{1}$ to 3 -carbomethoxyquinoline $\mathbf{6}$. Although limited in scope, this transformation provided some mechanistic considerations to a yet unexplored chemistry of alkyl azides. Allylic azides 1-3 also participate in tandem Staudinger/aza-Wittig reactions with $\mathrm{Ph}_{3} \mathrm{P}$ and aldehydes, generating multifunctional $N$-allylic imines 9-11 in high yield. The $(E)$-stereochemistry for both $\mathrm{C}=\mathrm{C}$ and $\mathrm{C}=\mathrm{N}$ bonds was assigned based on NOESY experiments. While the initial attempts to induce intramolecular cyclization to a 2-benzazepine framework were unsuccessful, the synthetic potential of these densely functionalyzed $N$-allylic imines 9-11 is evident and studies dealing with their reactivity and other chemical properties are currently being investigated.

\section{Experimental}

All chemicals were of reagent grade and were used as received. Melting points are uncorrected. ${ }^{1} \mathrm{H}$ NMR (200
$\mathrm{MHz})$ and ${ }^{13} \mathrm{C}$ NMR (50 MHz) spectra were recorded in $\mathrm{CDCl}_{3}$ solution, using tetramethylsilane as internal standard. Infrared spectra were acquired using $\mathrm{KBr}$ for solids and film for liquid samples. Mass spectra were determined at an ionizing voltage of $70 \mathrm{eV}$. Elemental analyses were performed with a CHN Perkin Elmer 2400 by UFSC-Central Analítica, Departamento de Química, Florianópolis, SC, Brazil. Column chromatography utilized silica gel (Aldrich, 100-200 mesh particle size). Allylic azides $\mathbf{1}$ and $\mathbf{2}$ were prepared according to the described method..$^{25}$

Methyl (E)-2-(acetoxymethyl)-3-(3,4-methylenedioxyphenyl)propenoate (5)

To a solution containing $2.10 \mathrm{~g}(8.9 \mathrm{mmol})$ of methyl 3-hydroxy-2-methylene-3-(3,4-methylenedioxyphenyl)propanoate $(4)^{26}$ in $3.0 \mathrm{~mL}$ of $\mathrm{CH}_{2} \mathrm{Cl}_{2}$ at $25^{\circ} \mathrm{C}$ was added $2.5 \mathrm{~mL}$ of acetic anhydride followed by $1.5 \mathrm{~mL}$ of pyridine. After stirring for $48 \mathrm{~h}$, the reaction mixture was diluted with $\mathrm{CH}_{2} \mathrm{Cl}_{2}$, washed with $\mathrm{H}_{2} \mathrm{O}, 10 \%$ aqueous $\mathrm{HCl}, 10 \%$ aqueous $\mathrm{NaHCO}_{3}$ and $\mathrm{H}_{2} \mathrm{O}$ again, dried over $\mathrm{Na}_{2} \mathrm{SO}_{4}$, filtered and concentrated under reduced pressure. The yellow oil obtained solidified on standing; recrystallization in diethyl ether/petroleum ether gave the product as colorless crystals ( $2.12 \mathrm{~g}, 86 \%$ yield), mp 89$90{ }^{\circ} \mathrm{C}$; IR $v_{\max } / \mathrm{cm}^{-1}: 1734,1714,1634,1228(\mathrm{KBr}) ;{ }^{1} \mathrm{H}$ NMR: $\delta 2.12$ (s, 3H, $\mathrm{CH}_{3} \mathrm{CO}$ ), 3.83 (s, 3H, $\left.\mathrm{OCH}_{3}\right), 4.96$ (s, $\left.2 \mathrm{H}, \mathrm{CH}_{2}\right), 6.01\left(\mathrm{~s}, 2 \mathrm{H}, \mathrm{OCH}_{2} \mathrm{O}\right), 6.90$ (m, 3H, H-Ar), 7.88 (s, $1 \mathrm{H}, H \mathrm{C}=) ;{ }^{13} \mathrm{CNMR}: \delta 21.0\left(\mathrm{CH}_{3}\right), 52.3\left(\mathrm{OCH}_{3}\right), 59.4\left(\mathrm{CH}_{2}\right)$, $101.6\left(\mathrm{OCH}_{2} \mathrm{O}\right), 108.7\left(\mathrm{HC}_{\mathrm{Ar}}\right), 109.4\left(\mathrm{HC}_{\mathrm{Ar}}\right), 124.8\left(C_{\alpha}\right)$, $125.0\left(\mathrm{HC}_{\mathrm{Ar}}\right), 128.2\left(C_{\mathrm{Ar}}\right), 145.4\left(C_{\beta}\right), 148.1\left(\mathrm{O} C_{\mathrm{Ar}}\right), 149.1$ $\left(\mathrm{O} C_{\mathrm{Ar}}\right), 167.5(\mathrm{COO}), 170.8(\mathrm{COO})$.

Methyl (E)-2-(azidomethyl)-3-(3,4-methylenedioxyphenyl)propenoate (3)

To a solution containing $0.80 \mathrm{~g}(2.9 \mathrm{mmol})$ of methyl (E) - 2-(acetox y methy 1$)-3-(3,4-$ me thy lene dioxyphenyl)propenoate (5) in $7.0 \mathrm{~mL}$ of DMSO at $25{ }^{\circ} \mathrm{C}$ was added $0.56 \mathrm{~g}(8.6 \mathrm{mmol})$ of sodium azide. After stirring for $40 \mathrm{~h}$, the reaction mixture was diluted with $\mathrm{CH}_{2} \mathrm{Cl}_{2}$, washed twice with $\mathrm{H}_{2} \mathrm{O}$, dried over $\mathrm{Na}_{2} \mathrm{SO}_{4}$, filtered and concentrated under reduced pressure. The yellow oil obtained solidified on standing; recrystallization in diethyl ether gave the product as colorless crystals $(0.62 \mathrm{~g}, 82 \%$ yield), mp 85-86 ${ }^{\circ} \mathrm{C}$; IR $v_{\max } / \mathrm{cm}^{-1}: 2110,1710,1625,1600$ (KBr); ${ }^{1} \mathrm{H}$ NMR: $\delta 3.87$ (s, $3 \mathrm{H}, \mathrm{OCH}_{3}$ ), 4.20 (s, 2H, $\mathrm{NCH}_{2}$ ), $6.02\left(\mathrm{~s}, 2 \mathrm{H}, \mathrm{OCH}_{2} \mathrm{O}\right), 6.80-7.00$ (m, 3H, H-Ar), 7.87 (s, $1 \mathrm{H}$, $H \mathrm{C}=$ ). Anal. Calcd. for $\mathrm{C}_{12} \mathrm{H}_{11} \mathrm{~N}_{3} \mathrm{O}_{4}: \mathrm{C}, 55.17 \% ; \mathrm{H}, 4.24 \%$; N, $16.08 \%$. Found: C, $55.52 \%$; H, 4.28\%; N, $16.48 \%$. 


\section{3-Carbomethoxyquinoline (6)}

To a solution containing $150 \mathrm{mg}(0.7 \mathrm{mmol})$ of methyl (E)-2-(azidomethyl)-3-phenylpropenoate (1) in $7.0 \mathrm{~mL}$ of anhydrous $\mathrm{CH}_{2} \mathrm{Cl}_{2}$ under nitrogen at $25{ }^{\circ} \mathrm{C}$ was added 140 $\mathrm{mg}(1.0 \mathrm{mmol})$ of $\mathrm{AlCl}_{3}$. The yellow solution was stirred at $25{ }^{\circ} \mathrm{C}$ for $30 \mathrm{~h}$, then another portion of $\mathrm{AlCl}_{3}$ was added (100 $\mathrm{mg}, 0.75 \mathrm{mmol}$ ), and the final orange solution was further stirred at $25^{\circ} \mathrm{C}$ for $24 \mathrm{~h}$. The reaction mixture was diluted with $\mathrm{CH}_{2} \mathrm{Cl}_{2}$, washed with saturated $\mathrm{NH}_{4} \mathrm{Cl}$ and $\mathrm{H}_{2} \mathrm{O}$, dried over $\mathrm{Na}_{2} \mathrm{SO}_{4}$, filtered and concentrated under reduced pressure. The resulting oil was purified by column chromatography on silica gel (hexane/ethyl acetate 2:1 as the eluent) to give $30 \mathrm{mg}(23 \%)$ of 3 carbomethoxyquinoline (6) as a clear solid, mp $74-77^{\circ} \mathrm{C}$ (Ref. 29: $\mathrm{mp} 73-74{ }^{\circ} \mathrm{C}$; $70-74{ }^{\circ} \mathrm{C}$ ); IR $v_{\max } / \mathrm{cm}^{-1}: 1735$ (KBr); ${ }^{1} \mathrm{H}$ NMR: $\delta 4.08$ (s, 3H, OCH${ }_{3}$ ), 7.80 (m, 2H, H-Ar), 8.05 (m, 2H, $H$-Ar), 8.63 (s, $1 \mathrm{H}, H$-Ar), 9.37 (s, $1 \mathrm{H}, H \mathrm{C}=\mathrm{N}) ;{ }^{13} \mathrm{CNMR}$ : $\delta 53.1\left(\mathrm{OCH}_{3}\right), 124.5\left(\mathrm{HC}_{\mathrm{Ar}}\right), 128.1\left(\mathrm{HC}_{\mathrm{Ar}}\right), 128.2\left(\mathrm{HC}_{\mathrm{Ar}}\right)$, $129.8\left(C_{\mathrm{Ar}}\right), 130.1\left(\mathrm{HC}_{\mathrm{Ar}}\right), 131.9\left(\mathrm{H}_{\mathrm{Ar}}\right), 135.7\left(C_{\mathrm{Ar}}\right), 140.3$ $\left(C_{\mathrm{Ar}}\right), 152.3(\mathrm{HC}=\mathrm{N}), 165.6(C O O) ; \mathrm{m} / \mathrm{z} 187\left(\mathrm{M}^{+}, 9 \%\right), 157$ (12), 129 (100), 101 (19), 77 (18), 51 (16).

\section{General procedure for Staudinger/Aza-Wittig reaction}

To a solution containing $1.0 \mathrm{mmol}$ of the respective allylic azide in $3.0 \mathrm{~mL}$ of anhydrous $\mathrm{CHCl}_{3}$ under nitrogen at $25^{\circ} \mathrm{C}$ was added $1.0 \mathrm{mmol}$ of triphenylphosphine. After stirring for 30-60 min the evolution of $\mathrm{N}_{2}$ ceased, and 1.0 mmol of the respective aldehyde was added to the solution. The final mixture was stirred at $25^{\circ} \mathrm{C}$ for further $20 \mathrm{~h}$, then was concentrated under reduced pressure to give a clear oil which was triturated with ethyl ether. Precipitated triphenylphosphine oxide (mp 157-158 ${ }^{\circ} \mathrm{C}$ ) was filtered off, the resulting filtrate was evaporated and the residue crystallized from ethyl ether, affording the imines as crystalline solids.

(1E,4E)-4-Carbomethoxy-1-(3-nitrophenyl)-5-phenyl-2azapenta-1,4-diene (9)

(84\% yield), mp $113-114{ }^{\circ} \mathrm{C}$; IR $v_{\max } / \mathrm{cm}^{-1}: 1694,1645$, 1628, 1526, 1350 (KBr); ${ }^{1} \mathrm{H}$ NMR: $\delta 3.81$ (s, 3H, $\mathrm{OCH}_{3}$ ), $4.70\left(\mathrm{~s}, 2 \mathrm{H}, \mathrm{CH}_{2}\right), 7.45$ (m, 3H, H-Ar), 7.60 (t, ${ }^{3} J 7.5 \mathrm{~Hz}, 1 \mathrm{H}$, $H$-Ar), 7.65 (m, 2H, H-Ar), 7.99 (s, $1 \mathrm{H}, H \mathrm{C}=$ ), 8.13 (d, ${ }^{3} J 7.5$ $\mathrm{Hz}, 1 \mathrm{H}, H$-Ar), 8.28 (d, ${ }^{3} J 7.5 \mathrm{~Hz}, 1 \mathrm{H}, H$-Ar), 8.54 (s, $1 \mathrm{H}, H$ $\mathrm{Ar}), 8.62(\mathrm{~s}, 1 \mathrm{H}, H \mathrm{C}=\mathrm{N}) ;{ }^{13} \mathrm{C} \mathrm{NMR}: \delta 52.2\left(\mathrm{OCH}_{3}\right), 56.8$ $\left(\mathrm{CH}_{2} \mathrm{~N}\right), 123-138\left(\mathrm{HC}_{\mathrm{Ar}} / C_{\mathrm{Ar}} / C_{\alpha}\right), 143.2\left(\mathrm{HC}_{\beta}=\right), 148.6(C-$ $\left.\mathrm{NO}_{2}\right), 160.5(\mathrm{HC}=\mathrm{N}), 168.0(\mathrm{COO})$. Anal. Calcd. for $\mathrm{C}_{18} \mathrm{H}_{16} \mathrm{~N}_{2} \mathrm{O}_{4}: \mathrm{C}, 66.66 \% ; \mathrm{H}, 4.97 \%$; N, 8.64\%. Found: C, $66.25 \% ; \mathrm{H}, 5.02 \%$; N, $8.51 \%$.
(1E,4E)-4-Carbomethoxy-1-(2-naphthyl)-5-phenyl-2azapenta-1,4-diene (10)

(88\% yield), mp 149-151 ${ }^{\circ} \mathrm{C}$; IR $v_{\max } / \mathrm{cm}^{-1}: 1710,1630$, 755, 700 (KBr); ${ }^{1} \mathrm{H}$ NMR: $\delta 3.81\left(\mathrm{~s}, 3 \mathrm{H}, \mathrm{OCH}_{3}\right), 4.71(\mathrm{~s}, 2 \mathrm{H}$, $\mathrm{NCH}_{2}$ ), 7.35-7.55 (m, 5H, H-Ar), 7.60-7.95 (m, 5H, H-Ar), $7.99(\mathrm{~s}, 1 \mathrm{H}, H \mathrm{C}=), 8.07(\mathrm{~m}, 2 \mathrm{H}, H-\mathrm{Ar}), 8.62(\mathrm{~s}, 1 \mathrm{H}, H \mathrm{C}=\mathrm{N})$; ${ }^{13} \mathrm{C}$ NMR: $\delta 52.1\left(\mathrm{OCH}_{3}\right), 56.7\left(\mathrm{CH}_{2} \mathrm{~N}\right), 124-135\left(\mathrm{HC}_{\mathrm{Ar}} l\right.$ $\left.\mathrm{C}_{\mathrm{Ar}} / C_{\alpha}\right), 142.8\left(\mathrm{HC}_{\beta}\right), 162.9(\mathrm{HC}=\mathrm{N}), 168.2(C O O)$. Anal. Calcd. for $\mathrm{C}_{22} \mathrm{H}_{19} \mathrm{NO}_{2}$ : C, 80.22\%; H, 5.81\%; N, $4.25 \%$. Found: C, $80.48 \%$; H, 5.84\%; N, 4.14\%.

(1E,4E)-4-Carbomethoxy-5-(3,4-methylenedioxyphenyl)1-(3-nitrophenyl)-2-azapenta-1,4-diene (11)

(76\% yield), mp 109-111 ${ }^{\circ} \mathrm{C}$; IR $v_{\max } / \mathrm{cm}^{-1}: 1692,1650$, 1618, 1596, 1534, 1346 (KBr); ${ }^{1} \mathrm{H}$ NMR: $\delta 3.79$ (s, 3H, $\left.\mathrm{OCH}_{3}\right), 4.69\left(\mathrm{~s}, 2 \mathrm{H}, \mathrm{NCH}_{2}\right), 6.02\left(\mathrm{~s}, 2 \mathrm{H}, \mathrm{OCH}_{2} \mathrm{O}\right), 6.88\left(\mathrm{~d},{ }^{3} \mathrm{~J}\right.$ $8.0 \mathrm{~Hz}, 1 \mathrm{H}, H$-Ar), 7.20 (d, ${ }^{3} J 8.0 \mathrm{~Hz}, 1 \mathrm{H}, H$-Ar), 7.34 (s, $1 \mathrm{H}$, $H$-Ar), 7.59 (t, ${ }^{3} J 7.5 \mathrm{~Hz}, 1 \mathrm{H}, H$-Ar), 7.88 (s, $\left.1 \mathrm{H}, H \mathrm{C}=\right), 8.13$ (d, ${ }^{3}$ 7 $7.5 \mathrm{~Hz}, 1 \mathrm{H}, H$-Ar), 8.27 (d, ${ }^{3} J 7.5 \mathrm{~Hz}, 1 \mathrm{H}, H$-Ar), 8.54 $(\mathrm{s}, 1 \mathrm{H}, H \mathrm{C}=\mathrm{N}), 8.60(\mathrm{~s}, 1 \mathrm{H}, H-\mathrm{Ar}) ;{ }^{13} \mathrm{CNMR}: \delta 52.1\left(\mathrm{OCH}_{3}\right)$, $56.7\left(\mathrm{CH}_{2} \mathrm{~N}\right), 101.5\left(\mathrm{OCH}_{2} \mathrm{O}\right), 108.6(C-3), 109.9(C-1)$, 123.2 (C-7), $125.1(C-6), 125.4(C-2), 126.4\left(C_{\alpha}\right), 129.0$ $\left(C_{\mathrm{Ar}}\right), 129.6(C-5), 133.8(C-4), 138.0\left(C_{\mathrm{Ar}}\right), 143.0(C-8)$, 148.1, 148.6, $148.8\left(2 \times \mathrm{OC}_{\mathrm{Ar}}+C-\mathrm{NO}_{2}\right), 160.4(\mathrm{HC}=\mathrm{N})$, 168.1 (COO). Anal. Calcd. for $\mathrm{C}_{19} \mathrm{H}_{16} \mathrm{~N}_{2} \mathrm{O}_{6}: \mathrm{C}, 61.96 \%$; $\mathrm{H}$, $4.38 \%$; N, 7.61\%. Found: C, 62.33\%; H, 4.51\%; N, 7.73\%.

\section{Acknowledgements}

M.M.S. is grateful to Central de Análises (Departamento de Química, UFSC) for analytical data, to Prof. Arlene G. Corrêa (UFSCar) for a generous gift of methyl acrylate, to Erica Silva Souza for a short-term participation in this work and to Dr. Emerson Meyer for helpful discussions.

\section{References}

1. Hassner, A. In Azides and Nitrenes; Scriven, E. F. V., ed., Academic: New York, 1984.

2. Taber, D. F. In Comprehensive Organic Synthesis; Pattenden, G., ed., Pergamon Press: Oxford, 1991, vol. 3, pp. 10451062.

3. Scriven, E. F. V.; Turnbull, K.; Chem. Rev. 1988, 88, 297.

4. Mazal, C.; Jonas, J.; Zak, Z.; Tetrahedron 2002, 58, 2729.

5. Gardiner, M.; Grigg, R.; Kordes, M.; Sridharan, V.; Vicker, N.; Tetrahedron 2001, 57, 7729.

6. Salunkhe, A. M.; Ramachandran, P. V.; Brown, H. C.; Tetrahedron Lett. 1999, 40, 1433. 
7. Aubé, J.; Badiang, J. G.; J. Org. Chem. 1996, 61, 2484.

8. Kita, Y.; Watanabe, H.; Egi, M.; Saiki, T.; Fukuoka, Y.; Tohma, H.; J. Chem. Soc., Perkin Trans. 1 1998, 635.

9. Pearson, W. H.; Suga, H.; J. Org. Chem. 1998, 63, 9910.

10. Gololobov, Y. G.; Kasukhin, L. F.; Tetrahedron 1992, 48, 1353.

11. Molina, P.; Vilaplana, M. J.; Synthesis 1994, 1197.

12. Staudinger, H.; Hauser, E.; Helv. Chim. Acta 1921, 4, 861.

13. Barluenga, J.; Ferrero, M.; Palacios, F.; J. Chem. Soc., Perkin Trans. 1 1990, 2193.

14. Koziara, A.; Zwierzak, A.; Synthesis 1992, 1063.

15. Zidani, A.; Carriè, R.; Vaultier, M.; Bull. Soc. Chim. Fr. 1992, 129, 71.

16. Hickey, D. M. B.; MacKenzie, A. R.; Moody, C. J.; Rees, C. W.; J. Chem. Soc., Perkin Trans. 1 1987, 921.

17. Katritzky, A. R.; Mazurkiewicz, R.; Stevens, C. V.; Gordeev, M. F.; J. Org. Chem. 1994, 59, 2740.

18. Sikora, D.; Gajda, T.; Tetrahedron 2000, 56, 3755.

19. Lundquist, J. T.; Pelletier, J. C.; Org. Letters 2001, 3, 781.

20. Padwa, A.; Sá, M. M.; Weingarten, M. D.; Tetrahedron 1997, 53, 2371.

21. Padwa, A.; Sá, M. M.; J. Braz. Chem. Soc. 1999, 10, 231; Padwa, A.; Sá, M. M.; Tetrahedron Lett. 1997, 38, 5087.

22. Sá, M. M.; Silveira, G. P.; Bortoluzzi, A. J.; Padwa, A.; Tetrahedron 2003, 59, 5441.

23. Basavaiah, D.; Rao, A. J.; Satyanarayana, T.; Chem. Rev. 2003, 103, 811; Ciganek, E.; Organic Reactions; Wiley \& Sons: N. Y., 1997, vol. 51, p. 201.

24. Patra, A.; Roy, A. K.; Batra, S.; Bhaduri, A. P.; Synlett 2002, $11,1819$.

25. Foucaud, A.; Guemmout, F. E.; Bull. Soc. Chim. Fr. 1989 , 403.

26. Almeida, W. P.; Coelho, F.; Tetrahedron Lett. 1998, 39, 8609.
27. Mason, P. H.; Emslie, N. D.; Tetrahedron 1994, 50, 12001.

28. Basavaiah, D.; Sarma, P. K. S.; Bhavani, A. K. D.; J. Chem. Soc., Chem. Commun. 1994, 1091.

29. Uhle, F.; Jacobs, W. A.; J. Org. Chem. 1945, 10, 76; Cain, M.; Weber, R. W.; Guzman, F.; Cook, J. M.; Barker, S. A.; Rice, K. C.; Crawley, J. N.; Paul, S. M.; Skolnick, P.; J. Med. Chem. 1982, 25, 1081.

30. Tojo, T.; Spears, G. W.; Tsuji, K.; Nishimura, H.; Ogino, T.; Seki, N.; Sugiyama, A.; Matsuo, M.; Bioorg. Med. Chem. Lett. 2002, 12, 2427; Erickson, E. H.; Hainline, C. F.; Lenon, L. S.; Matson, C. J.; Rice, T. K.; Swingle, K. F.; Winkle, M. V.; J. Med. Chem. 1979, 22, 816

31. Kim, J. N.; Chung, Y. M.; Im, Y. J.; Tetrahedron Lett. 2002, 43, 6209; Kim, J. N.; Lee, H. J.; Lee, K. Y.; Kim, H. S.; Tetrahedron Lett. 2001, 42, 3737.

32. Kita, Y.; Watanabe, H.; Egi, M.; Saiki, T.; Fukuoka, Y.; Tohma, H.; J. Chem. Soc., Perkin Trans. 1 1998, 635.

33. We thank one referee for a critical intervention, providing the following lead references: Takeuchi, H.; Maeda, M.; Mitani, M.; Koyama, K.; J. Chem. Soc., Perkin Trans. 1 1987, 57; Abramovitch, R. A.; Barton, D. H. R.; Finet, J.-P.; Tetrahedron 1988, 44, 3039.

34. Bloch, R.; Chem. Rev. 1998, 98, 1407.

35. Grunewald, G. L.; Dahanukar, V. H.; Ching, P.; Criscione, K. R.; J. Med. Chem. 1996, 39, 3539; Kouznetsov, V.; Palma, A.; Salas, S.; Vargas, L. Y.; Zubkov, F.; Varlamov, A.; Martínez, J. R.; J. Heterocycl. Chem. 1997, 34, 1591.

36. Clark, M. T.; Chang, J.; Navran, S. S.; Akbar, H.; Mukhopadhyay, A.; Amin, H.; Feller, D. R.; Miller, D. D.; J. Med. Chem. 1986, 29, 181.

Received: March 11, 2003 Published on the web: November 28, 2003 